\title{
Shelf Life Extensions of Pear cv. Nashpati using Shrink Wrapping in East Siang District of Arunachal Pradesh, India
}

\author{
Ng. Piloo , S.R. Singh, O. Messar and A.K. Pandey \\ College of Horticulture and Forestry, Central Agricultural University, Pasighat, \\ Arunachal Pradesh, India \\ *Corresponding author
}

\section{A B S T R A C T}

\section{Keywords}

Pear fruit, Nashpati, shelf life, Heat shrinkable films, Storage, Quality

\section{Article Info}

Accepted:

12 April 2018

Available Online:

10 May 2018
Pear cv. Nashpati were subjected to three treatments viz. $\mathrm{T}_{1}$ (Individual Shrink wrapping), $\mathrm{T}_{2}$ (Shrink Wrapping in trays) and $\mathrm{T}_{3}$ (Control treatment) were stored in ambient condition (29-32 ${ }^{\circ} \mathrm{C}$ temperature and $55-78 \%$ relative humidity) in which periodical observations were recorded on physiological loss in weight (PLW, \%), total soluble solid (TSS, ${ }^{\circ}$ Brix), titratable acidity (mg of malic acid/g), decay loss (\%) and sensory quality (\%) at Department of Post-Harvest Management, College of Horticulture and Forestry, Arunachal Pradesh, India during the year 2017-2018. Result showed reduced rate of PLW $(3.134 \%)$ and postharvest decay losses $(30 \%)$ along with marketable quality of fruit having TSS $\left(9.7^{\circ}\right.$ Brix) and acidity $(0.224 \%)$ in $\mathrm{T}_{1}$ upto 20 days of storage as compared to other treatment. Hence, $\mathrm{T}_{1}$ (Individual Shrink wrapping) was the most suitable packaging material for extending the shelf life of pear fruits upto 20-25 days at ambient condition with least PLW and maintaining the marketable fruit quality, which can be recommended for the pear grower for increasing the shelf life and better income generation in the near future of this region.

\section{Introduction}

Pear, a typical fruit of temperate climates, with delicate pleasant taste and smooth, has a wide acceptance throughout the world. It is mainly consumed in natura, pies, cakes, accompanying strong cheese, jams, and ice creams and is a great fruit to be consumed in diets because of its low caloric value. It has high nutritional value with reasonable amounts of vitamins $\mathrm{A}, \mathrm{B}_{1}, \mathrm{~B}_{2}, \mathrm{~B}_{3}$ and $\mathrm{C}$ and minerals like sodium, potassium, phosphorus, calcium, magnesium and iron. It has a lot of fiber, giving excellent results in the treatment of constipation and intestine inflammation. Many recommend pears to cure anomalies such as cystitis and kidney stones (Gonsalves, 2002). Ancient Greek poet Homer described Pears as one of the 'gifts of God'. This prehistoric fruit has been under cultivation both in Europe and Asia for long times (Hedrick et al., 1921). Sand pear (Japanese and Chinese species) has been domesticated as edible fruit and cultivated in Asia for more than 3000 years (Lombard and Westwood, 1987). Advances in pear culture and varietal improvement were brought only in the $18^{\text {th }}$ century. In Asia, China and Japan are the 
leading pear growing countries where its cultivation remained in a semi-wild state for a long time (Kaur and Arya, 2012). In India, pear is next only to apple in importance, acreage, production and varietals diversity among temperate fruits in India. It is grown under temperate and subtropical conditions because of its wider climatic and soil adaptability. It is primarily grown in hills at $1,700-2,400 \mathrm{~m}$ above mean sea-level in the states of Himachal Pradesh, Jammu and Kashmir and Uttar Pradesh. Low-chilling pears have adapted very well in the subtropical regions (Chadha, 2001). In North East region of India, pear cv. Nashpati or Sandpear is grown mainly in Manipur, Meghalaya, Arunachal Pradesh, Sikkim and Nagaland. However, still now it is grown in the homestead garden or grown in the forest area as underutilized fruit crops. It is commonly known as Nashpati in this region and people like this fruit for fresh consumption.

However, due to high moisture content in the fruit it has short post-harvest shelf life resulting very short period availability in the market. Over the last 5-10 years, a change in attitude is noticed among the policy makers and general public with regard to quality and/or standard of life which ultimately demands quality as well as diverse source of food.

The Global Forum on Agriculture Research (GFAR) in 1999 also emphasized the role of underutilized species in raising income of the rural poor. These novel crops also will help these rural sectors in mitigating the malnutrition and hence enabling them a quality life (Swaminathan, 1999). Therefore, in the present study, an attempt has been made to evaluate the shelf life of pear cv. Nashpati by using individual and tray wrapping to extend the available period in East Siang district of Arunachal Pradesh, India.

\section{Materials and Methods}

\section{Experimental site}

The present investigation was undertaken in the College of Horticulture and Forestry, Central Agricultural University, Pasighat, Arunachal Pradesh, under the Department of Post-Harvest Management during the period from August to September 2017.

\section{Raw materials}

Freshly harvested, pear cv. locally known as Nashpati fruits free from blemishes obtained from Pasighat market, East Siang district of Arunachal Pradesh were used for the experiment. Precautions were taken while handling the produce to minimize abrasions and bruising which leads to accelerated spoilage and rotting.

\section{Preparation of samples}

Mature sand pear fruits of uniform size were washed with tap water to remove the dirt and then surface dried at room temperature by spreading it in blotting paper for 20-30 minutes.

The pears were then subjected to the following treatments viz. $T_{1}$-Individual wrapping with heat shrinkable film $(15 \mu) ; \quad \mathrm{T}_{2}$-Tray overwrapped with heat shrinkable film $(15 \mu)$; $\mathrm{T}_{3}$-No wrapping (open condition). The pears in heat shrinkable films were passed through a shrink wrapping machine (Chamber machine: $15 \mathrm{X} 20)$ at $150^{\circ} \mathrm{C}$ for $10-15$ seconds. The pear fruits in different packages were stored in cool, dry place on racks at room temperature in the laboratory of the Department of PostHarvest Management during the period from August to September, 2016. The average temperature and relative humidity during storage period varied from 29 to $32^{\circ} \mathrm{C}$ and 55 to $78 \%$ respectively. 


\section{Observation}

\section{Physiological loss in weight (\%)}

Assam Lemon fruits were weighed initially and at 2 days intervals during storage. The results were expressed as

$$
\text { PLW }(\%)=\frac{\text { Initial weight-Final weight }}{\text { Initial weight }} \times 100
$$

\section{Total Soluble Solids}

The total soluble solids (TSS) of the fruit juice were determined using a hand refractometer and expressed as per cent TSS after making the temperature correction at $20^{\circ} \mathrm{C}$.

\section{Titratable acidity}

The titratable acidity as percent citric acid of the Juice was determined, using the method described in AOAC (1995).

\section{Decay (\%)}

Decay was recorded by visual observation of the numbered fruits at regular intervals by counting the number of decayed fruits.

\section{Sensory quality}

Sensory quality was recorded by visual observation of the numbered fruits at regular intervals for their general appearance and acceptability depending upon the condition of the fruits (Worawaran et al., 2013). The assessment was carried out at the beginning of the experiment and on the $5^{\text {th }}, 10^{\text {th }}, 15^{\text {th }}, 20^{\text {th }}$ and $25^{\text {th }}$ day of storage.

\section{Marketability (\%)}

The number of fruits acceptable by consumer in each experimental lot on the day of observation was recorded and expressed in percentage (Assumi et al., 2009).

\section{Statistical analysis}

The statistical analysis of various characters studied in this experiment was carried out as per the procedure appropriate to the design of experiment i.e. 2 factor factorial Completely Randomized Design by adopting the Statistical procedures given by Gomez and Gomez (1984).

\section{Results and Discussion}

\section{PLW}

A significant $(\mathrm{p}<0.05)$ difference in weight loss was observed among the packed and unpacked pears which increases with advancement of storage period. However, the lemons packed individually in heat shrinkable films show the lowest weight loss $(4.075 \%)$ compared with the tray packed ones $(5.619 \%)$ on the $24^{\text {th }}$ day of storage (Table 1). The PLW for the unpacked pears were as high as $13.480 \%$ on the $12^{\text {th }}$ day of storage. The lower weight loss in $\mathrm{T}_{1}$ might be due to increase in $\mathrm{CO}_{2}$ concentration, low oxygen atmosphere and decrease in transpiration rate due to higher RH inside (Wang 1977; Gorini and Uncini 1981; Mercado et al., 1995). Reduction in PLW or decay loss may primarily be due to creation of modified atmosphere around the fruits by the gas permeability properties of shrinkable films (Ben-Yehoshua, 2005; BenYehoshua et al., 1983). Condensation of water droplets was observed in overwrapped trays.

\section{TSS}

The total soluble solids (TSS) of wrapped and unwrapped fruits were observed to increase during storage (Table 2). Lowest TSS $\left(9.76^{\circ} \mathrm{Brix}\right)$ was observed in $\mathrm{T}_{1}$ [Individual wrapping with heat shrinkable film $(15 \mu)]$ followed by $\mathrm{T}_{2}$ [Tray overwrapped with heat shrinkable film $(15 \mu)]$ with $9.96^{\circ}$ Brix on $25^{\text {th }}$ day of storage and $\mathrm{T}_{3}$ [No wrapping] with $12.00^{\circ}$ Brix on the $15^{\text {th }}$ day of storage. 
Table.1 PLW (\%) of pears as affected by wrapping at different days of storage

\begin{tabular}{|c|c|c|c|c|c|c|c|c|c|c|c|c|}
\hline Treatment & 2 & 4 & 6 & 8 & 10 & 12 & 14 & 16 & 18 & 20 & 22 & 24 \\
\hline $\mathrm{T}_{1}$ & 0.314 & 0.626 & 0.941 & 1.253 & 1.567 & 1.880 & 2.507 & 2.822 & 2.822 & 3.134 & 3.448 & 4.075 \\
\hline$\frac{1}{T_{2}}$ & 0.638 & 1.149 & 1.532 & 1.787 & 2.043 & 2.554 & 2.809 & 3.330 & 3.449 & 4.469 & 4.980 & 5.619 \\
\hline $\mathbf{T}_{\mathbf{3}}$ & 3.479 & 6.958 & 7.825 & 9.140 & 11.737 & 13.480 & 15.217 & 16.962 & 19.565 & 20.868 & 23.475 & 26.083 \\
\hline Mean & 1.47 & 2.91 & 3.43 & 4.06 & 5.11 & 5.97 & 6.84 & 7.70 & 8.61 & 9.49 & 10.63 & 11.92 \\
\hline CD@5\% & -- & 0.003 & 0.006 & 0.012 & 0.008 & 0.012 & 0.002 & 0.014 & 0.007 & 0.003 & 0.012 & 0.005 \\
\hline $\mathrm{SEM} \pm \mathrm{m}$ & -- & 0.001 & 0.002 & 0.003 & 0.002 & 0.003 & 0.001 & 0.003 & 0.002 & 0.001 & 0.004 & 0.001 \\
\hline
\end{tabular}

$\mathrm{T}_{1}$-Individual wrapping with heat shrinkable film $(15 \mu) ; \mathrm{T}_{2}$-Tray overwrapped with heat shrinkable film $(15 \mu) ; \mathrm{T}_{3^{-}}$ No wrapping (open condition)

Table.2 TSS ( ${ }^{\circ}$ Brix) of Pears as affected by wrapping at different days of storage

\begin{tabular}{|c|c|c|c|c|c|c|}
\hline Treatment & ODAS & 5DAS & 10DAS & 15DAS & 20DAS & 25DAS \\
\hline $\mathbf{T}_{1}$ & 9.0 & 9.40 & 9.56 & 9.53 & 9.70 & 9.76 \\
\hline $\mathbf{T}_{2}$ & 9.0 & 9.20 & 9.40 & 9.60 & 9.80 & 9.96 \\
\hline $\mathbf{T}_{3}$ & 9.0 & 9.76 & 9.96 & 12.00 & - & - \\
\hline Mean & 9.0 & 9.54 & 9.64 & 10.37 & 6.1 & 6.57 \\
\hline CD@5\% & ----- & 0.17 & 0.14 & 0.17 & 0.16 & 0.09 \\
\hline $\mathrm{SEM} \pm \mathrm{m}$ & ----- & 0.04 & 0.02 & 0.05 & 0.02 & 0.03 \\
\hline
\end{tabular}

$\mathrm{T}_{1}$-Individual wrapping with heat shrinkable film $(15 \mu) ; \mathrm{T}_{2}$-Tray overwrapped with heat shrinkable film $(15 \mu) ; \mathrm{T}_{3^{-}}$ No wrapping (open condition)

Table.3 Titratable acidity (\%) of pears as affected by wrapping at different days of storage

\begin{tabular}{|c|c|c|c|c|c|c|}
\hline Treatment & \multicolumn{1}{|c|}{ 0DAS } & 5DAS & 10 DAS & 15 DAS & 20 DAS & 25 DAS \\
\hline $\mathrm{T}_{1}$ & 0.448 & 0.362 & 0.352 & 0.224 & 0.224 & $\mathbf{0 . 2 0 0}$ \\
\hline $\mathrm{T}_{2}$ & 0.448 & 0.352 & 0.320 & 0.288 & 0.214 & 0.192 \\
\hline $\mathrm{T}_{3}$ & 0.448 & 0.382 & 0.187 & 0.193 & -- & -- \\
\hline Mean & $\mathbf{0 . 4 4 8}$ & $\mathbf{0 . 3 6 5}$ & $\mathbf{0 . 2 6 8}$ & $\mathbf{0 . 2 3 5}$ & $\mathbf{0 . 2 1 9}$ & $\mathbf{0 . 1 9 6}$ \\
\hline CD@5\% & - & - & $\mathbf{0 . 0 6 8}$ & $\mathbf{0 . 0 0 1}$ & $\mathbf{0 . 0 0 2}$ & $\mathbf{0 . 0 0 1}$ \\
\hline SEM $\pm m$ & - & - & $\mathbf{0 . 0 2}$ & $\mathbf{0 . 0 0 3}$ & $\mathbf{0 . 0 0 6}$ & $\mathbf{0 , 0 0 3}$ \\
\hline
\end{tabular}

$\mathrm{T}_{1}$-Individual wrapping with heat shrinkable film $(15 \mu) ; \mathrm{T}_{2}$-Tray overwrapped with heat shrinkable film $(15 \mu) ; \mathrm{T}_{3^{-}}$ No wrapping (open condition) 
Table.4 Decay (\%) of pears as affected by wrapping during different days of storage in ambient condition

\begin{tabular}{|c|c|c|c|c|c|c|}
\hline Treatment & ODAS & 5DAS & 10 DAS & 15 DAS & 20 DAS & 25 DAS \\
\hline $\mathrm{T}_{1}$ & 0 & 0 & 0.000 & 21.667 & 30.000 & $\mathbf{3 0 . 0 0 0}$ \\
\hline $\mathrm{T}_{2}$ & 0 & 0 & 5.333 & 23.333 & 48.333 & 48.333 \\
\hline $\mathrm{T}_{3}$ & 0 & 0 & 21.667 & 53.333 & -- & -- \\
\hline Mean & $\mathbf{0}$ & $\mathbf{0}$ & $\mathbf{1 3 . 5}$ & $\mathbf{3 2 . 7 7}$ & $\mathbf{2 6 . 1 1}$ & $\mathbf{3 8 . 3 3}$ \\
\hline CD@5\% & -- & -- & $\mathbf{3 . 3 9}$ & $\mathbf{5 . 7 6}$ & $\mathbf{3 . 5 2}$ & $\mathbf{3 . 5 2}$ \\
\hline SEM $\pm m$ & -- & -- & $\mathbf{1 . 1 3}$ & $\mathbf{1 . 4 4}$ & $\mathbf{1 . 1 7}$ & $\mathbf{0 . 8 8}$ \\
\hline
\end{tabular}

$\mathrm{T}_{1}$-Individual wrapping with heat shrinkable film $(15 \mu) ; \mathrm{T}_{2}$-Tray overwrapped with heat shrinkable film $(15 \mu) ; \mathrm{T}_{3^{-}}$ No wrapping (open condition)

Table.5 Sensory quality of lemon as affected by wrapping during different days of storage in ambient condition

\begin{tabular}{|c|c|c|c|c|c|c|}
\hline \multirow{2}{*}{ Treatment } & \multicolumn{7}{|c|}{ Days after Storage } \\
& 0DAS & 5DAS & 10DAS & 15DAS & 20DAS & 25DAS \\
\hline $\mathrm{T}_{1}$ & 5 & 5 & 5 & 5 & 4 & 4 \\
\hline $\mathrm{T}_{2}$ & 5 & 5 & 4 & 4 & 4 & 3 \\
\hline $\mathrm{T}_{3}$ & 5 & 4 & 3 & 2 & 1 & 1 \\
\hline
\end{tabular}

Pear fruits were rated for visual quality, wilting and shriveling, using a scale of 1 to 5 in which $5=$ excellent, 4=good, $3=$ unacceptable, $2=$ poor and $1=$ very poor. Fruit appearance was rated "unacceptable" when the score was less than or equal 3.

Table.6 Marketability (\%) of pears as affected by wrapping at different days of storage in ambient condition

\begin{tabular}{|c|c|c|c|c|c|c|}
\hline Treatment & \multicolumn{5}{|c|}{ Days after Storage } \\
\cline { 2 - 7 } & 0DAS & 5DAS & 10DAS & 15DAS & 20DAS & 25DAS \\
\hline $\mathrm{T}_{1}$ & 100 & 100 & 100 & 96.67 & 86.67 & 76.67 \\
\hline $\mathrm{T}_{2}$ & 100 & 100 & 100 & 76.67 & 66.67 & 53.33 \\
\hline $\mathrm{T}_{3}$ & 100 & 79.67 & 56.67 & 44.67 & -- & -- \\
\hline
\end{tabular}

$\mathrm{T}_{1}$-Individual wrapping with heat shrinkable film $(15 \mu) ; \mathrm{T}_{2}$-Tray overwrapped with heat shrinkable film $(15 \mu) ; \mathrm{T}_{3^{-}}$ No wrapping (open condition)

The total soluble solids (TSS) of fruits stored in all the packaging materials were observed to increase during storage. Increase in TSS could be as a result of the breakdown of organic polymers into simple sugars as reported by Faseema et al., (2011) and Mahajan and Singh (2014).

\section{Titratable acidity}

The titratable acidity of fruits decreases during storage irrespective of the packaging treatments (Table 3). $\mathrm{T}_{1}$ has the highest acidity of $0.200 \%$ on the $25^{\text {th }}$ day of storage followed by $\mathrm{T}_{2}$ with $0.192 \%$. Generally 
organic acids usually decline during ripening of fruits as they are used as substrates for respiration or converted into sugars and their further utilization in the metabolic process of the fruits (Faseema et al., 2011). In shrink wrapped fruits the lowering of acidity was delayed which might be due to the effect of shrink packaging film in delaying the respiratory and ripening process (Mahajan et al., 2013).

\section{Decay and sensory quality}

Decay percentage was as low as $30.0 \%$ for $\mathrm{T}_{1}$ and $48.33 \%$ for $\mathrm{T}_{2}$ on $25^{\text {th }}$ day of storage. However, T3 had a higher decay percentage of more than 50 even on the $15^{\text {th }}$ day of storage (Table 4 ). $\mathrm{T}_{1}$ had a good sensory score of 4 even on the $25^{\text {th }}$ day of storage (Table 5). However $\mathrm{T}_{2}$ and $\mathrm{T}_{3}$ had a score of 3 and 1 on the $25^{\text {th }}$ day of storage.

\section{Marketability}

Marketability of $\mathrm{T}_{1}$ [Individual wrapping with heat shrinkable film $(15 \mu)]$ was as high as $76.67 \%$ on the $25^{\text {th }}$ day of storage while $\mathrm{T}_{2}$ [Tray overwrapped with heat shrinkable film $(15 \mu)]$ with $53.33 \%$ on the $25^{\text {th }}$ day of storage (Table 6). Marketability of $\mathrm{T}_{3}$ [No wrapping] was as low as $44.67 \%$ on the $15^{\text {th }}$ day of storage.

In summary, considering all the physical and quality parameters, it is concluded that $\mathrm{T}_{1}$ (Individual Shrink wrapping) was the superior treatment because of high marketable fruits $(76.67 \%)$, low physiological loss in weight $(4.075 \%)$, TSS $\left(9.76^{\circ}\right.$ Brix), titratable acidity $(0.20 \%)$ with better sensory score (4) with a shelf life of 20-25 days followed by followed by $\mathrm{T}_{2}$ (Shrink Wrapping in trays) and $\mathrm{T}_{3}$ (Control treatment) with 10-15days and 810days respectively. Therefore, that $\mathrm{T}_{1}$ (Individual Shrink wrapping) can be recommended to the pear growers to increase the self-life under ambient condition and need to be further verified under adverse climatic conditions.

\section{Acknowledgement}

The authors like to render gratefulness to the College of Horticulture \& Forestry, Central Agricultural University for allowing the research work for this underutilized fruit crop.

\section{References}

AOAC (1995). Official Method of Analysis.16th ed. Arlington, V.A. Association of official analytical chemist. Pp. 806-842.

Assumi SR, Piloo Ng, Kabir J (2009). Storage behaviour of okra (Abelmoschus esculentus L. Moench) as influence by prepackaging in polyethylene bags. Crop Res., 37: 107-111.

Ben-Yehoshua S (2005). Environmentally Friendly Technologies for Agricultural Produce Quality, Culinary \& Hospitality Industry Publication Services, Texas USA, 552 pp.

Ben-Yehoshua S, Shapiro B, Even-Chen Z and Lurie $S$ (1983). Mode of action of plastic film in extending life of lemon and bell pepper fruits by alleviation of water stress. Plant Physiol. 73:87-93.

Chadha, K.L. (2001). Pear. In: Hand Book of Horticulture. Published by Directorate of Information and Publications of Agriculture, Indian Council of Agricultural Research, New Delhi, pp. 267-271.

Faasema J, Abu JO and Alakali JS (2011).Effect of packaging and storage condition on the quality of sweet orange (Citrus cinesis). Journal of Agricultural Technology, Vol. 7(3): 797-804.

Gomez KA, Gomez AA (1984). Statistical procedures for Agricultural research $\left(2^{\text {nd }}\right.$ ed.). A Wiley- inter science 
Publication (John Wiley and Sons) New York, USA

Gonsalves, P. E. (2002). "As frutas e seus benef'1cios," in Frutas Que Curam, vol. 1, pp. 131-166.

Gorini FL, Uncini L (1981). Influence of packing on quality of hot peppers. Atti dell' Istituto Sperimentale per la Valorizzazione Tecnologica dei Prodotti Agricoli, Milano, 4:127-131.

Hedrick, U.P., Howe, G.H., Taylor, O.M., Francis, E.H. and Turkey, H.B. (1921). The pears of New York. 29th Annual Report, New York Department of Agriculture. JB Lyon Co. Printers, Albany, New York.

Kaur, R.and Arya, V. (2012). Ethnomedicinal and phytochemical perspectives of Pyrus communis Linn. Journal of Pharmacognosy and Phytochemistry, 1(2): 14-19.

Mahajan BVC, Kumar D and Dhillon WS (2013). Effect of different polymeric films on the shelf life and quality of pear fruits under supermarket conditions. Indian Journal of Horticulture, 70: 309-312.
Mahajan, BVC and Singh R (2014).Effect of packaging films on shelf life and quality of kinnow fruits packed in consumer packages. International Journal of Farm Sciences, 4(1): 92-98.

Mercado JA, Quesada MA, Valpuesta V, Reid $M$ and Cantwell M (1995). Storage of bell peppers in controlled atmospheres at chilling and non chilling temperatures. Acta Hort., 412:134-142.

Swaminathan, M. S. (1999). Enlarging the basis of food security. The role of underutilized species. International workshop held at the M. S. Swaminathan Research Foundation, 1719, February, Chennai, India.

Wang CY (1977). Effect of CO, treatment on storage and shelf life of sweet peppers. J Am Soc Hort Sci., 102: 808-812.

Worawaran R, Nithiya R, Nappol L and Danai B (2013). Influence of Storage Conditions on Physico-Chemical and Biochemical of Two Tangerine Cultivars. Journal of Agricultural Science, 5(2): 70-84.

\section{How to cite this article:}

Piloo, Ng, S.R. Singh, O. Messar and Pandey, A.K. 2018. Shelf Life Extensions of Pear cv. Nashpati using Shrink Wrapping in East Siang District of Arunachal Pradesh, India. Int.J.Curr.Microbiol.App.Sci. 7(05): 1504-1510. doi: https://doi.org/10.20546/ijcmas.2018.705.176 